\title{
Bibliometric Analysis and Review of Halal Tourism
}

\author{
Sutan Emir Hidayat ${ }^{1^{*}}$, Ahmad Rafiki ${ }^{2}$, Muhammad Dharma Tuah Putra Nasution ${ }^{3}$ \\ ${ }^{1}$ Universitas Gunadarma, Indonesia \\ ${ }^{1}$ Komite Nasional Ekonomi dan Keuangan Syariah, Indonesia \\ 2Universitas Medan Area, Indonesia \\ 3Universitas Pembangunan Panca Budi, Indonesia \\ E-mail: ${ }^{1}$ sutan.knks@gmail.com, ${ }^{2}$ ahmadrafiki@staff.uma.ac.id, ${ }^{3}$ dharmatuah@gmail.com
}

") Corresponding author

JEL Classification:

M31

$\mathrm{Z12}$

$\mathrm{Z} 30$

Z31

$\mathrm{Z} 32$

Received: January 15, 2021

Revised: April 2, 2021

Accepted: May 7, 2021

\begin{abstract}
The purpose of this paper is to review the existing works and literature on halal tourism using bibliometric analysis in an attempt to explore the expanding journey of this concept since its conceptualization. Based on a bibliometric analysis of 77 articles retrieved from the Scopus database from 2004 to Sept 2020, this study employs the following bibliometric techniques such as citation, co-citation, and co-occurrence of author keywords. This study finds the nature and direction of research on halal tourism had been conducted over the past decades. It also finds the most dominant authors, journals, institutions, and countries about the works on halal tourism. However, using a single source of the database could be a limitation of this study that, thus expectedly, additional techniques are needed for future researches. For academicians and practitioners, they could get comprehensive insights on the halal tourism concept from this study, which can reference strategic initiatives to encourage Muslim traveler loyalty and obtain Muslim tourist satisfaction.
\end{abstract}

\section{Keywords:}

halal tourism, muslim friendly tourism, bibliometric analysis, citation analysis.

How to Cite:

Hidayat, S. E., Rafiki, A., \& Nasution, M. D. T. P. (2021). A Bibliometric Analysis and Review of Halal Tourism. Signifikan: Jurnal Ilmu Ekonomi, 10(2), 177-194. https://doi.org/10.15408/sjie.v10i2.20270. 


\section{Introduction}

The research on the interrelationship between religion and tourism would be an interesting topic in some countries. However, due to the high sensitivity of the subject, the researchers must be very selective and careful. Thus the topic of religious tourism is still open to be explored and studied (Collins-Kreiner \& Wall, 2015; Kartal et al., 2015; El-Gohary, 2016). On another side, the scholars perceived that some ideas or basic concepts of the religious tourism industry had been discussed but might need to expand with significant findings (El-Gohary, 2016). For example, every Muslim had visited the holy cities of Mecca and El-Madena to conduct Hajj as required in the Islamic teachings; this indicated that religious or halal tourism is begun. Historically, Muslims had visited other religious places around the world. However, these days, when religious tourism extended to halal tourism. Thus the topic is open to be studied as long as the principles and requirements comply with shari'ah (Islamic law) (El-Gohary, 2016).

Moreover, tourism and hospitality are considered an element closely related to social and cultural, which then represent the dimensions of ethnicity and religion (Stephenson et al., 2010), which means that tourism is not only perceived in the Islamic view but may associate with other religions. However, the segment of Muslim tourists or Islamic tourism has enormous potentials and was aimed as a progressive industry such as Turkey, Egypt, or Palestine, or by the Muslim minority countries that invited the Muslim tourists to their places like Korea and Japan. The State of the Global Islamic Economy Report in 2019, \$189 billion of spending in Muslim-friendly travels, which $\$ 1.8$ billion of it spent by Muslims. The market in this sector is estimated will reach to $\$ 274$ billion in 2024. Based on the indicator ranking set by the Dinar Standard, Malaysia is recognized as a country that fulfills all the criteria, followed by United Arab Emirates (UAE) and Turkey in the second and third place. However, the Muslim minority countries like Thailand are in the top ten ranks. This report tells that Muslim tourism is tremendously acknowledged, and the market itself is growing significantly.

The literature reveals that the tourism products and services that cater to the needs of Muslim tourists are conceptualized as "Halal tourism," "Islamic tourism," or "Muslim friendly tourism," or "Sharia tourism." These terms are relatively new in the academic literature and appear as a new type of tourism (Yagmur et al., 2019; El-Gohary, 2016; Bhuiyan et al., 2011; Ryan, 2016). However, those terms have not clearly defined the attributes to distinguish them (Khan \& Callanan, 2017). Nevertheless, these entire terms can be defined as travel with the core motive of experiencing religious forms, or the products they induce, like art, culture, traditions, and architecture (FICCI Religious Tourism Report, 2012).

Halal tourism is one of the emerging concepts related to the halal concept and has been defined differently. Simply, the halal concept refers to the permissible activities based on the sharia that Muslims must obey. Not all activities are allowed in the halal concept and must be with good conduct (Mohsin et al., 2016; Battour \& Ismail, 2016). This concept can be easily related to tourism activities whereby usually there is no limit for such activities in hotels, resorts, restaurants, beaches, other recreational places, or 
promotional and marketing-related activities. This concept includes tour packages and destinations that are particularly designed to cater to Muslim considerations and needs. Halal tourism has concern and very selective in choosing activities that comply with sharia (Jafari \& Scott, 2014). Zamani-Farahani \& Henderson (2010) added that halal tourism is the type of tourism, which mainly attracts Muslims who prefer to stay in their own culture, while Ala-Hamarneh (2011) described halal tourism consists of as an economic, cultural, and religious concept (El-Gohary, 2016).

In comparison, Duman (2011) highlighted that it is a concept of Islamic motivationbased tourism activities that are carried out following the rules of sharia. Halal tourism is comprised and interrelated to other elements such as halal food, halal transportation, halal hotel, halal logistics, Islamic finance, Islamic travel packages, and halal spa (El-Gohary, 2016). Again, this concept is meant for tourists of both Muslims and non- Muslims in specific Muslim and non-Muslim destinations of the tourism industry.

Meanwhile, there are many terms related to halal tourism, such as Islamic tourism, Sharia tourism, and Muslim Friendly Tourism.

Islamic tourism is well-rooted in sharia (Islamic law) and had been practicing from the early days of the Islamic civilization till today which seen when all Muslims are required to perform Hajj or Umrah or in other words, some of them visit the sacred places as obligated by the sharia (El-Gohary, 2016). Meanwhile, Henderson (2010) referred the Islamic tourism as the product development and marketing efforts that have been designed for and directed at Muslims. Other defined Islamic tourism as "a type of religious tourism that is in conformity with Islamic teachings regarding behaviorisms, dress, conduct, and diet" (Battour et al., 2010), and Jafari \& Scott (2014) mentioned that Islamic tourism offers a new touristic meaning of pilgrimage that merges religious and leisure tourism which far from the hedonistic perspective. These concluded that Islamic or halal tourism concept and practice is guided by the Islamic principles that emphasize ethical, moral, good customs/manners and attempts giving choice, option, and preference than mainstream tourism activities. Islamic tourism focuses on various issues such as participation and engagement (by Muslims), tourism places and destinations (Islamic destinations), product(s) (residential places, food, entertainment, beverage), dimensions (social, economic, cultural, religious), and managing the offered service processes (marketing, ethical considerations) (Duman, 2011; Tajzadeh, 2013).

Sharia Tourism is used mainly by Indonesian researchers and not in other countries. This condition because the use of Islamic or Islam words is considered sensitive by other perspectives or groups. Although sometimes, the meanings become narrow because 'sharia' refers only to Islamic law, rather than the word 'Islam' that has a more comprehensive understanding. All Islamic institutions called sharia bank, sharia rural bank, sharia restaurants, sharia hotels, sharia insurance also had used this term. Moreover, sharia tourism is the preferred term of some tourism destinations in Indonesia, such as Lombok, also known as one of the best destinations to visit, promoting self-styled Island of 1000 mosques (Osman, 2013; AFP 2015). This data includes the initiative that comes from the 
Indonesian government that highlights Lombok as the archipelago's best 'sharia tourism destinations' (AFP 2015; Delaney 2015).

The term Muslim Friendly Tourism emerged due to being adapted to the surrounding environment, such as the minority Muslim society or countries such as Korea, Japan, or United Kingdom. It tries to delete the words 'sharia' or 'Islam.' However, the meaning is similar, which refers to the tourism product(s) or activities that must be halal (permissible) which comply with the rules and guidelines set by the sharia (Islamic law). Examples of initiatives that those minority societies had done were serving the halal food in their restaurants, having a place to pray (salat) and a clean environment, staying in a hotel with no prostitution or any other immoral activities. These might be the issues, challenges, and difficulties by them, but somehow, when they perceived this concept would bring businesses than the values, thus they accept it. They realized the benefit of halal products/environment is good for them in that sense. Meanwhile, due to certain conditions of reluctance in some countries, the halal tourism term is changed to just "Muslim friendly" tourism (El-Gohary, 2016).

Given the importance of this subject, practitioners and academicians expectedly will get some valuable insights, thus essential to have a proper understanding of this subject's progress and potential for further applicability in other disciplines. Also, due to the recent exponential increase in the halal tourism literature and limitations in the methodological approach employed, therefore there is a need for a rigorous review in a more systematic and well-rounded manner using bibliometric analysis. The use of a comprehensive study in the form of a bibliometric analysis would explore the halal tourism literature for 16 years since 2004. To the best of our knowledge, the studies by Yagmur et al. (2019) and Ismail et al. (2019) are the only bibliometric analyses carried out so far on Halal tourism.

Bibliometric analysis is a meta-analytical research technique that summarizes a set of bibliographic papers to show the interconnections among articles based on multiple measures by analyzing citations and co-citations using quantitative methods and indicating key research themes related to a given topic, i.e., halal tourism. Thus in this study, expectedly, the most eminent contributors of a given subject will be identified, most dominant papers and journals will be identified, and sequent progress in the subject will be elaborated.

\section{Methods}

A rigorous bibliometric analysis in this study aimed to address all the pre-defined research questions. Bibliometric analysis manifests interconnections among the articles regarding the frequency with which an article is cited and co-cited by other articles, as seen in Table 1.

This study has retrieved data from Scopus, a comprehensive database used extensively by various researchers to carry out bibliometric analysis in multiple domains. The primary reason for choosing Scopus is its availability, nearly 60 percent larger than the Web of Science (WoS) database (Zhao \& Strotmann, 2015). The authors, hence, searched for articles that would be relevant for this study from the Scopus database with the following 
titles; "Halal Tourism," "Islamic Tourism," "Muslim Friendly Tourism," "Sharia Tourism," "Halal Friendly Tourism." The study limits its analysis only to the discipline of "business" and "management," which emphasizes halal tourism.

Table 1. Search syntax on Scopus database

\begin{tabular}{ll}
\hline \multicolumn{1}{c}{ Data Source } & \multicolumn{1}{c}{ Search syntax } \\
\hline & TITLE ( "islamic tourism" OR "halal tourism" OR "muslim friendly tourism" OR \\
"sharia tourism" OR "halal friendly tourism") AND ( EXCLUDE ( SUBJAREA, "ENGI" & )) AND ( EXCLUDE ( SUBJAREA, "BIOC") ) AND ( EXCLUDE ( SUBJAREA, "AGRI" \\
Search syntax on Scopus & ) AND ( EXCLUDE ( SUBJAREA, "MEDI") ) AND ( EXCLUDE ( SUBJAREA, "PSYC" \\
database & ) AND ( EXCLUDE ( SUBJAREA, "DECI") ) AND ( EXCLUDE ( SUBJAREA, "EART" \\
& ))AND ( EXCLUDE ( SUBJAREA, "COMP") ) AND ( EXCLUDE ( DOCTYPE, "cp" ) ) \\
\hline
\end{tabular}

Source: Author compilation

The publication dates of the articles range from 2004 to 2020. Additionally, articles and reviews were published only in journals considered for this study, while conference papers are excluded from this study, and the articles were published only in English (see Table 1). Moreover, a review or search query is based on the retrieved total of 77 articles. The query begins with searching for the indicated keywords in the parts of the journals, such as a title. A thorough review is done based on 77 selected articles.

\section{Result and Discussion}

In this part, the results of the analysis using the techniques of bibliometric analysis are elaborated. Firstly, it would present the citation analysis results, sequentially followed by analyses of co-citation and co-occurrence of author keywords. There are items to be reviewed in this citation analysis, such as the number of publications per year, most cited documents; most dominant authors; most dominant journals; most dominant institutions, and most dominant countries.

As depicted Table 2, it shows a total of 77 articles from 40 journals, written by 179 authors affiliated to 95 institutions from 29 countries, with a total number of references cited of 1111 . These general results give a portrait of all the articles being reviewed on the subject of halal tourism.

Table 2. General Results

\begin{tabular}{lc}
\hline \multicolumn{1}{c}{ Summary of General Results } \\
Criteria & Quantity \\
\hline Articles & 77 \\
Journals & 40 \\
Authors & 176 \\
Institutions & 95 \\
Countries & 29 \\
Cited references & 1111 \\
\hline
\end{tabular}


The trend in the number of publications on halal tourism from 2004 to 2020 shows two interesting stages. First, from 2004 to 2014 is the beginning of the concept of Islamic and halal tourism in the context of the tourism business. Publications in those years were the highest point in 2014. During the 2014-2020 period, there was an increase in the number of publications that were more than twice the initial stage. The year 2019 presents the highest number of publications compared to 2016, with a slight increase in 2020 (see Figure 1). However, looking at the trend in the number of publications received up to the third quarter of 2020. It can be assumed that the following years tend to be more constant compared to the year 2019.

Figure 1. Number of publications per year

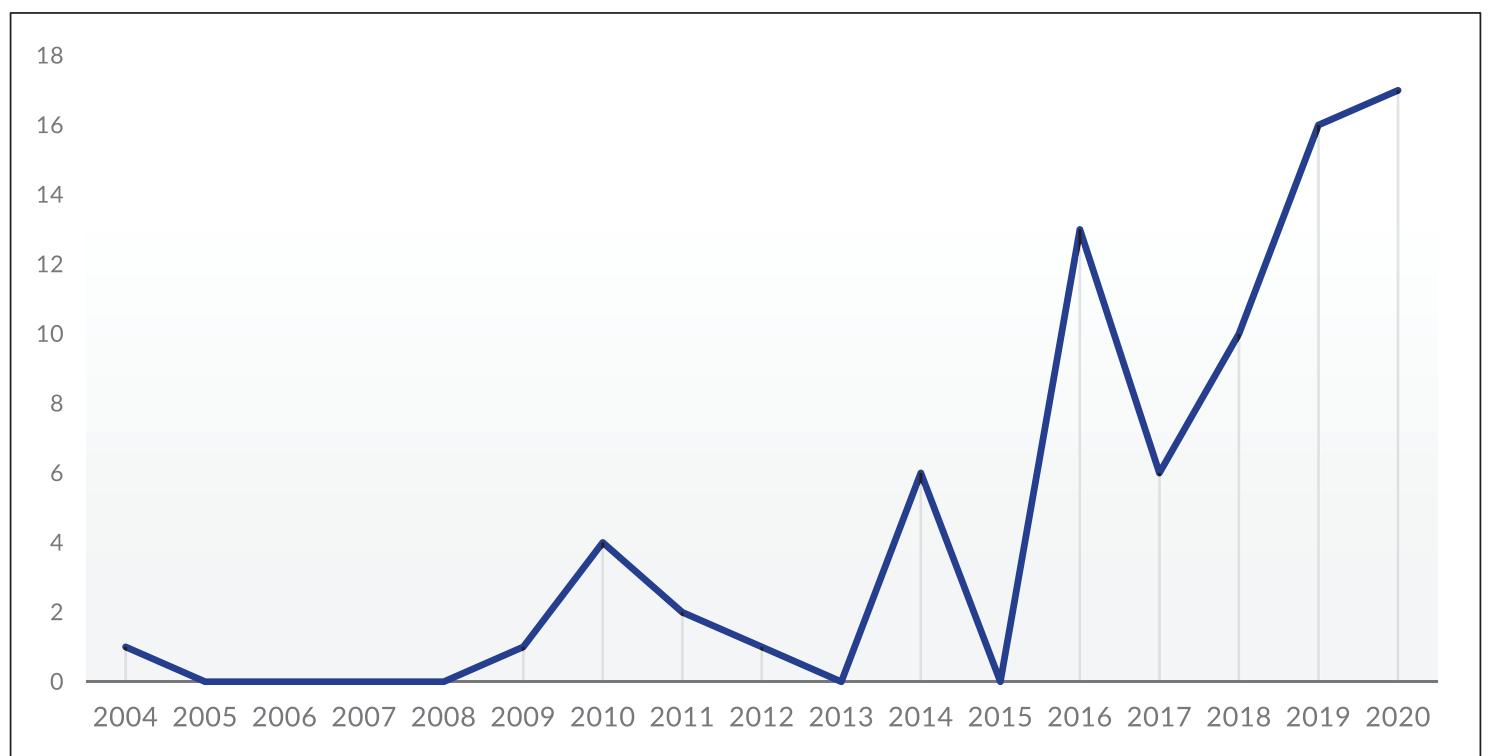

As depicted in Table 3, there are 23 most cited documents with at least ten citations in the subject of Islamic and Halal Tourism. The documents are ranked in descending order of the number of citations received. Twenty-three articles received at least ten citations for 91 percent of the total cited documents or more. The article by Zamani-Farahani \& Henderson (2010) is the most cited article with 159 citations. In this article, the authors explain, Islam has proven to have significant consequences on the conditions of incoming and outgoing tourists and destinations and has an influence in setting the content, direction, and application of tourism policies. The impact on tourism in Islamic countries such as Iran and Saudi Arabia might dictate societal and economic behavior. Although the countries have many unique tourist spots, they only attract relatively few tourists from developed countries. Thus those countries do not get the full benefits from tourism industry in terms of the economic or business income except the pilgrims who came purposely in fulfilling the obligation of the religion. It seems that the Islamic countries have a severe barrier to tourism development, but at the same time, it must be acknowledged that certain types of development are not always desirable, and officials and residents may deem the absence of large numbers of Western tourists highly desirable. 
Furthermore, the next most cited article is the work of Al-Hamarneh \& Steiner (2004). In this article, the author conceptualizes Islamic tourism as having real opportunities only if the intra-regional political situation and cooperation in travel and visa issuance are accepted widely. Cultural and religious concepts can play a positive role as complementary options in the tourism landscape. Hence, these two articles are related to the conceptualization and definition of tourism in Islam and eventually receive a very high number of citations in the halal tourism papers.

Table 3. Most cited documents in Islamic and Halal Tourism Literature

\begin{tabular}{|c|c|c|c|}
\hline Rank & Document & Author & Citation \\
\hline 1 & $\begin{array}{l}\text { Islamic tourism and managing tourism } \\
\text { development in Islamic societies: The cases of Iran } \\
\text { and Saudi Arabia }\end{array}$ & $\begin{array}{l}\text { (Zamani-Farahani \& } \\
\text { Henderson, 2010) }\end{array}$ & 159 \\
\hline 2 & $\begin{array}{l}\text { Islamic tourism: Rethinking the strategies of } \\
\text { tourism development in the Arab world after } \\
\text { September 11, } 2001\end{array}$ & $\begin{array}{l}\text { (Al-Hamarneh \& Steiner, } \\
\text { 2004) }\end{array}$ & 110 \\
\hline 3 & $\begin{array}{l}\text { Halal tourism: Concepts, practices, challenges and } \\
\text { future }\end{array}$ & (Battour \& Ismail, 2016) & 95 \\
\hline 4 & Toward a halal tourism market & $\begin{array}{l}\text { (Battour, Ismail, \& Battor, } \\
\text { 2010) }\end{array}$ & 63 \\
\hline 5 & Halal tourism: Emerging opportunities & (Mohsin et al., 2016) & 61 \\
\hline 6 & $\begin{array}{l}\text { Islamic tourism: an empirical examination of travel } \\
\text { motivation and satisfaction in Malaysia }\end{array}$ & (Battour et al., 2017) & 60 \\
\hline 7 & Halal tourism, is it really Halal? & (El-Gohary, 2016) & 58 \\
\hline 8 & $\begin{array}{l}\text { Halal food, certification and halal tourism: Insights } \\
\text { from Malaysia and Singapore }\end{array}$ & (Henderson, 2016) & 48 \\
\hline 9 & Islamic Tourism Reviewed & (Henderson, 2009) & 40 \\
\hline 10 & $\begin{array}{l}\text { The capacity of New Zealand to accommodate the } \\
\text { halal tourism market - Or not }\end{array}$ & $\begin{array}{l}\text { (Razzaq, Hall \& Prayag, } \\
\text { 2016) }\end{array}$ & 36 \\
\hline 11 & $\begin{array}{l}\text { Is Islamic tourism a viable option for Tunisian } \\
\text { tourism? Insights from Djerba }\end{array}$ & $\begin{array}{l}\text { (Carboni, Perelli \& Sistu, } \\
\text { 2014) }\end{array}$ & 35 \\
\hline 12 & $\begin{array}{l}\text { Current trends on Halal tourism: Cases on selected } \\
\text { Asian countries }\end{array}$ & $\begin{array}{l}\text { (Samori, Md Salleh \& } \\
\text { Khalid, 2016) }\end{array}$ & 33 \\
\hline 13 & Halal tourism & (Ryan, 2016) & 25 \\
\hline 14 & $\begin{array}{l}\text { Halal tourism: antecedent of tourist's satisfaction } \\
\text { and word of mouth (WOM) }\end{array}$ & $\begin{array}{l}\text { (Wardi, Abror \& Trinanda, } \\
\text { 2018) }\end{array}$ & 24 \\
\hline 15 & $\begin{array}{l}\text { Potentials of Islamic tourism: A case study of } \\
\text { Malaysia on East Coast Economic Region }\end{array}$ & (Bhuiyan et al., 2011) & 24 \\
\hline 16 & Halal tourism de facto: A case from Fez & $\begin{array}{l}\text { (Carboni \& Idrissi Janati, } \\
\text { 2016) }\end{array}$ & 21 \\
\hline 17 & Halal tourism: state of the art & $\begin{array}{l}\text { (Vargas-Sánchez \& Moral- } \\
\text { Moral, 2019) }\end{array}$ & 18 \\
\hline
\end{tabular}




\begin{tabular}{|c|c|c|c|}
\hline Rank & Document & Author & Citation \\
\hline 18 & $\begin{array}{l}\text { Muslim tourist perceived value: a study on } \\
\text { Malaysia Halal tourism }\end{array}$ & $\begin{array}{l}\text { (Isa, Chin \& Mohammad, } \\
\text { 2018) }\end{array}$ & 14 \\
\hline 19 & $\begin{array}{l}\text { Islamic tourism as an ideological construction: } \\
\text { A Jordan study case }\end{array}$ & (Neveu, 2010) & 14 \\
\hline 20 & Halal tourism: conceptual and practical challenges & (Boğan \& Sarışık, 2019) & 13 \\
\hline 21 & $\begin{array}{l}\text { The perception of non-Muslim tourists towards } \\
\text { halal tourism: Evidence from Turkey and Malaysia }\end{array}$ & (Battour et al., 2018) & 13 \\
\hline 22 & $\begin{array}{l}\text { The invention of al-Andalus: discovering the } \\
\text { past and creating the present in Granada's } \\
\text { Islamic tourism sites }\end{array}$ & (Calderwood, 2014) & 13 \\
\hline 23 & $\begin{array}{l}\text { The impact of Halal tourism, customer } \\
\text { engagement on satisfaction: moderating effect } \\
\text { of religiosity }\end{array}$ & (Abror et al., 2019) & 12 \\
\hline
\end{tabular}

As depicted in Table 4, it shows the most dominant authors in the halal tourism subject. The influence of the authors is measured by the number of articles they have published about halal tourism vis-a-vis the citations received by each of them. In terms of the total number of citations received, Henderson and Battour are the most dominant authors, with 247 and 239 citations.

Table 4. Most Dominant Authors (in terms of total citations received)

\begin{tabular}{clcc}
\hline Rank & \multicolumn{1}{c}{ Author } & Document & Citation \\
\hline 1 & Henderson J.C. & 3 & 247 \\
2 & Battour M. & 5 & 239 \\
3 & Ismail M.N. & 5 & 239 \\
4 & Zamani-Farahani H & 2 & 159 \\
5 & Battor M. & 3 & 131 \\
6 & Al-Hamarneh A. & 1 & 110 \\
7 & Steiner C. & 1 & 110 \\
8 & Awais M. & 2 & 68 \\
9 & El-Gohary H. & 2 & 67 \\
10 & Mohsin A. & 2 & 61 \\
\hline
\end{tabular}

As depicted in Table 5, shows that the average of citations per document led by Al-Hamarneh and Steiner as the most dominant authors with 110 and 110 citations per document, respectively.

As depicted in Table 6, it shows the most dominant journals have narrated about the concept of halal tourism where the Journal of Islamic Marketing has a higher rank with the number of published articles of 12 and followed by Tourism Management Perspectives 
with the number of published articles of 10 . On the total number of citations received, the Tourism Management Perspectives attests as the most dominant journal with a total of citations of 413 , followed by the International Journal of Tourism Research with a total citation of 159 .

Table 5. Most Dominant Authors (in terms of average citation per document)

\begin{tabular}{clccc}
\hline Rank & \multicolumn{1}{c}{ Author } & Document & Citation & Average citation per document \\
\hline 1 & Al-Hamarneh A. & 1 & 110 & 110 \\
2 & Steiner C. & 1 & 110 & 110 \\
3 & Henderson J.C. & 3 & 247 & 82.3 \\
4 & Zamani-Farahani H & 2 & 159 & 79.5 \\
5 & Ramli N. & 1 & 61 & 61 \\
6 & Alkhulayfi B.A. & 1 & 61 & 61 \\
7 & Battour M. & 5 & 239 & 47.8 \\
8 & Ismail M.N. & 5 & 239 & 47.8 \\
9 & Battor M. & 3 & 131 & 43.7 \\
10 & Razzaq S. & 1 & 36 & 36 \\
\hline
\end{tabular}

Table 6. Most Dominant Journals (in terms of the total article published)

\begin{tabular}{|c|c|c|c|}
\hline Rank & Journal & Article & Citation \\
\hline 1 & Journal of Islamic Marketing & 12 & 50 \\
\hline 2 & Tourism Management Perspectives & 10 & 413 \\
\hline 3 & Tourism Analysis & 3 & 74 \\
\hline 4 & Current Issues in Tourism & 3 & 68 \\
\hline 5 & Asia Pacific Journal of Tourism Research & 3 & 39 \\
\hline 6 & Tourism Recreation Research & 2 & 41 \\
\hline 7 & Tourism Review & 2 & 24 \\
\hline 8 & Journal of Travel and Tourism Marketing. & 2 & 12 \\
\hline 9 & International Journal of Tourism Research & 1 & 159 \\
\hline 10 & Comparative Studies of South Asia, Africa and the Middle East & 1 & 110 \\
\hline
\end{tabular}

As depicted in Table 7, shows the average citations received per article, whereby the International Journal of Tourism Research attests as the most dominant journal with 159 average citations per article; followed by Comparative Studies of South Asia, Africa, and the Middle East with average citations per article at 110. 
Table 7. Most Dominant Journals (in terms of average citation per document)

\begin{tabular}{clccc}
\hline Rank & \multicolumn{1}{c}{ Journal } & Article & Citation & $\begin{array}{c}\text { Average citation } \\
\text { per document }\end{array}$ \\
\hline 1 & International Journal of Tourism Research & 1 & 159 & 159 \\
2 & $\begin{array}{l}\text { Comparative Studies of South Asia, Africa, and the } \\
\text { Middle East }\end{array}$ & 1 & 110 & 110 \\
3 & Tourism Management Perspectives & 10 & 413 & 41.3 \\
4 & Tourism Analysis & 3 & 74 & 24.7 \\
5 & Current Issues in Tourism & 3 & 68 & 22.7 \\
6 & Tourism Recreation Research & 2 & 41 & 20.5 \\
7 & Asia Pacific Journal of Tourism Research & 3 & 39 & 13 \\
8 & Tourism Review & 2 & 24 & 12 \\
9 & Journal of Travel and Tourism Marketing. & 2 & 12 & 6 \\
10 & Journal of Islamic Marketing & 12 & 50 & 4.1 \\
\hline
\end{tabular}

As depicted in Table 8 shows the most dominant institutions that have published articles on halal tourism. The institutions are plotted based on the authors who have published articles, received citations, and affiliations were with those institutions. On the total number of published articles, the University of Malaya and Tanta University is in the top list, while for the total citations received, the University of Malaya is the highest in the rank with a total citation of 508, followed by the Nanyang Technological University with a count of 247.

Table 8. Most Dominant Institutions (in total citations received)

\begin{tabular}{clccc}
\hline Rank & \multicolumn{1}{c}{ Institution } & Country & Document & Citation \\
\hline 1 & University of Malaya & Malaysia & 7 & 508 \\
2 & Nanyang Technological University & Singapore & 3 & 247 \\
3 & Tanta University & Egypt & 4 & 231 \\
4 & Middlesex University & United Kingdom & 2 & 68 \\
5 & Universiti Utara Malaysia & Malaysia & 2 & 68 \\
6 & International Islamic University of Malaysia & Malaysia & 1 & 61 \\
7 & University of Waikato & New Zealand & 1 & 61 \\
8 & Cairo University & Egypt & 1 & 58 \\
9 & Birmingham City University & United Kingdom & 1 & 58 \\
10 & University of Canterbury & New Zealand & 1 & 36 \\
\hline
\end{tabular}

As depicted in Table 9, based on the average of citations received per article, Nanyang Technological University is the most dominant institution with 82.3 average 
citations per document, followed by the University of Malaya with average citations per document of 72.3 .

Table 9. Most Dominant Institutions (in average citation per document)

\begin{tabular}{clcccc}
\hline Rank & \multicolumn{1}{c}{ Institution } & Country & Document & Citation & $\begin{array}{c}\text { Average citation } \\
\text { per document }\end{array}$ \\
\hline 1 & Nanyang Technological University & Singapore & 3 & 247 & 82.3 \\
2 & University of Malaya & Malaysia & 7 & 508 & 72.3 \\
3 & $\begin{array}{l}\text { International Islamic University of } \\
\text { Malaysia }\end{array}$ & Malaysia & 1 & 61 & 61 \\
4 & University of Waikato & New Zealand & 1 & 61 & 61 \\
5 & Cairo University & Egypt & 1 & 58 & 58 \\
6 & Birmingham City University & United & 1 & 58 & 58 \\
7 & Tanta University & Kingdom & & & 57.5 \\
8 & University of Canterbury & New Zealand & 1 & 36 & 36 \\
9 & Linnaeus University & Sweden & 1 & 36 & 36 \\
10 & University of Johannesburg & South Afrika & 1 & 36 & 35 \\
\hline
\end{tabular}

Table 10 shows the most dominant countries with highly cited papers related to halal tourism. Based on the total citations received, Malaysia attests to be the most dominant country with a citation count of 561, followed by Egypt with a count of 307 .

Table 10. Most Dominant Countries (in total citations received)

\begin{tabular}{clcc}
\hline Rank & Country & Document & Citation \\
\hline 1 & Malaysia & 25 & 561 \\
2 & Egypt & 8 & 307 \\
3 & Singapore & 3 & 247 \\
4 & United kingdom & 5 & 144 \\
5 & New Zealand & 5 & 97 \\
6 & Italy & 4 & 58 \\
7 & Indonesia & 16 & 47 \\
8 & South Africa & 3 & 40 \\
9 & Sweden & 1 & 36 \\
10 & Turkey & 4 & 28 \\
\hline
\end{tabular}


However, based on the average citation per document, interestingly, the country of Singapore is in the top list, as seen in Table 11, where the publications of highly cited articles belong to the authors from this country. Other dominant countries are Egypt, Sweden, and the United Kingdom, with some average citations per document of $38.3,36$, and 28.8 , respectively.

Table 11. Most Dominant Countries (in average citation per document)

\begin{tabular}{|c|c|c|c|c|}
\hline Rank & Country & Document & Citation & $\begin{array}{c}\text { Average citation per } \\
\text { document }\end{array}$ \\
\hline 1 & Singapore & 3 & 247 & 82.3 \\
\hline 2 & Egypt & 8 & 307 & 38.3 \\
\hline 3 & Sweden & 1 & 36 & 36 \\
\hline 4 & United kingdom & 5 & 144 & 28.8 \\
\hline 5 & Malaysia & 25 & 561 & 22.4 \\
\hline 6 & Marocco & 1 & 21 & 21 \\
\hline 7 & New Zealand & 5 & 97 & 19.4 \\
\hline 8 & Italy & 4 & 58 & 14.5 \\
\hline 9 & South Africa & 3 & 40 & 13.3 \\
\hline 10 & Denmark & 1 & 12 & 13 \\
\hline
\end{tabular}

This analysis describes the results of author co-citation with cited authors. Based on the analysis of the cited references of the 77 articles, 1086 authors have been identified. Then this set was narrowed down to authors with at least 20 citations resulting in 64 articles. While based on the co-citation analysis as depicted in Figure 2, it shows the most frequently cited authors in sequence are Battour M (95 citations), Henderson J.C (88 citations), Mohsin (61 citations), El-Gohary (58 citations), Carboni (35 citations) and Samori (33 citations). This list of frequently cited authors exhibits the tremendous contributions to halal tourism literature.

A co-citation analysis was conducted to search the most frequently cited journals. This analysis describes the results of co-citation journals with cited journals. As depicted in Figure 3, it shows, the most frequently cited journals are the Tourist Management, Tourist Management Perspective, Journal of Islamic Marketing, Annal of Tourism Research, and International Journal of Tourism Research. This list of frequently cited journals means the significance of these journals for researchers interested in the halal tourism subject. 
Figure 2. Network of co-cited authors

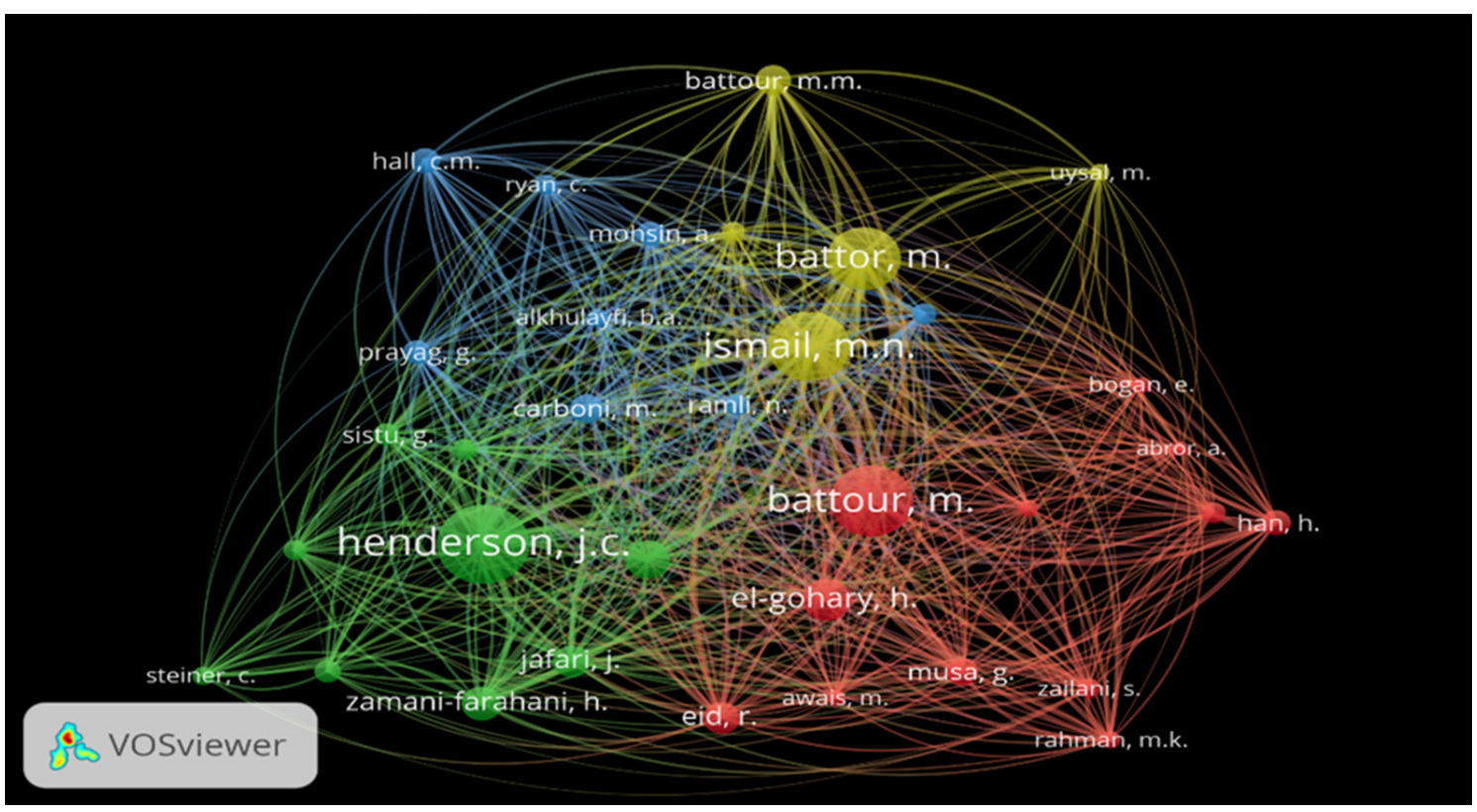

Figure 3. Network of co-cited journals

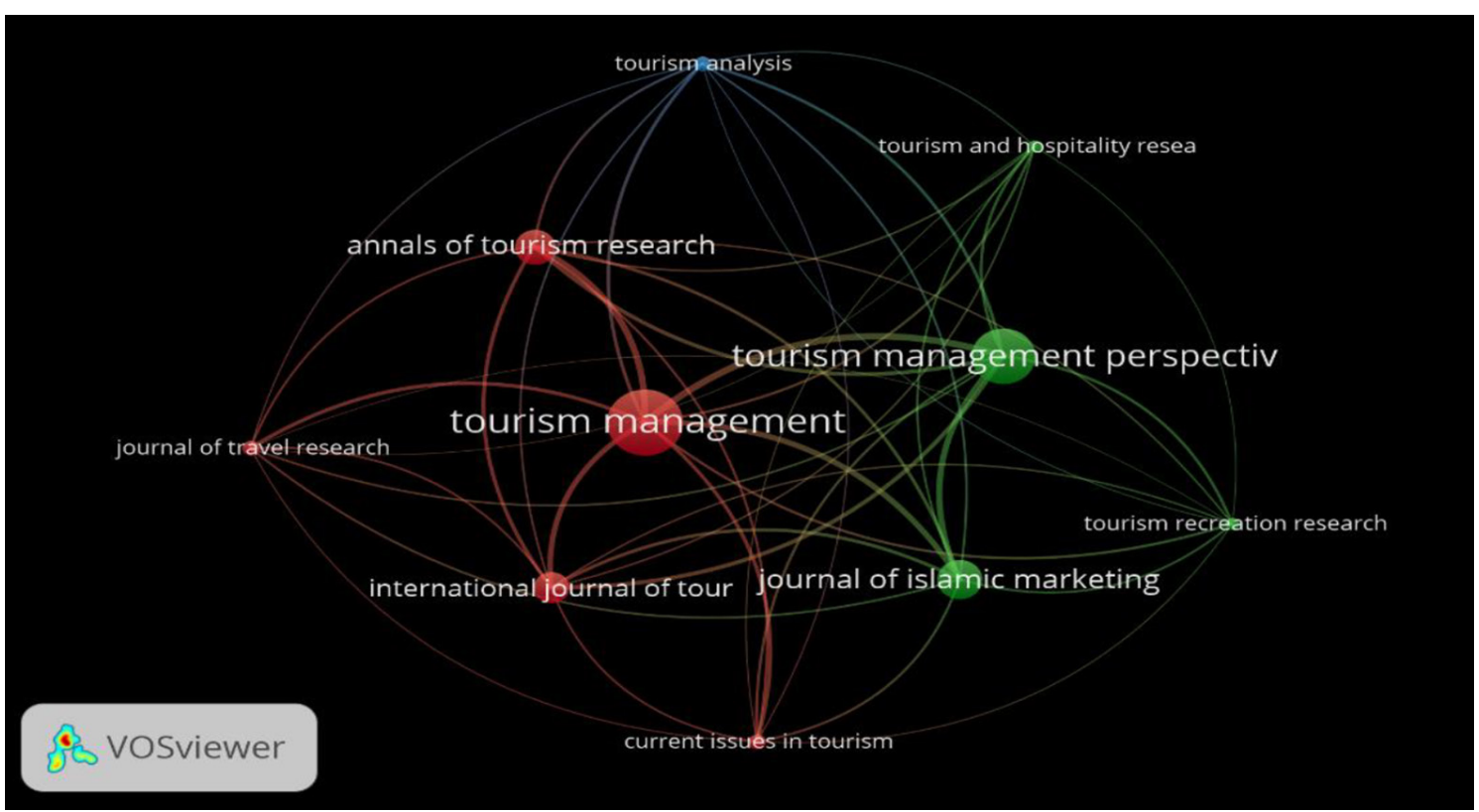

This analysis describes the most frequently used keywords. As depicted in Figure 4, it illustrates the terms of 'halal tourism,' 'Islamic tourism,' 'halal hospitality,' 'destination marketing,' 'halal,' 'tourism,' 'Islam,' 'satisfaction' and 'halal product' are considered as the most eminent keywords in the halal tourism papers over the past 16 years. Some other encouraging keywords to be adopted for future works on halal tourism are 'halal-friendly tourism,' 'Muslim friendly tourism,' 'halal tangible attributes,' 'halal intangible attributes', 'Muslim friendly zone,' and 'Muslim friendly destination.' These keywords give precious information on the central concepts in halal tourism literature over the years. 
Figure 4. Co-occurrence of author keywords

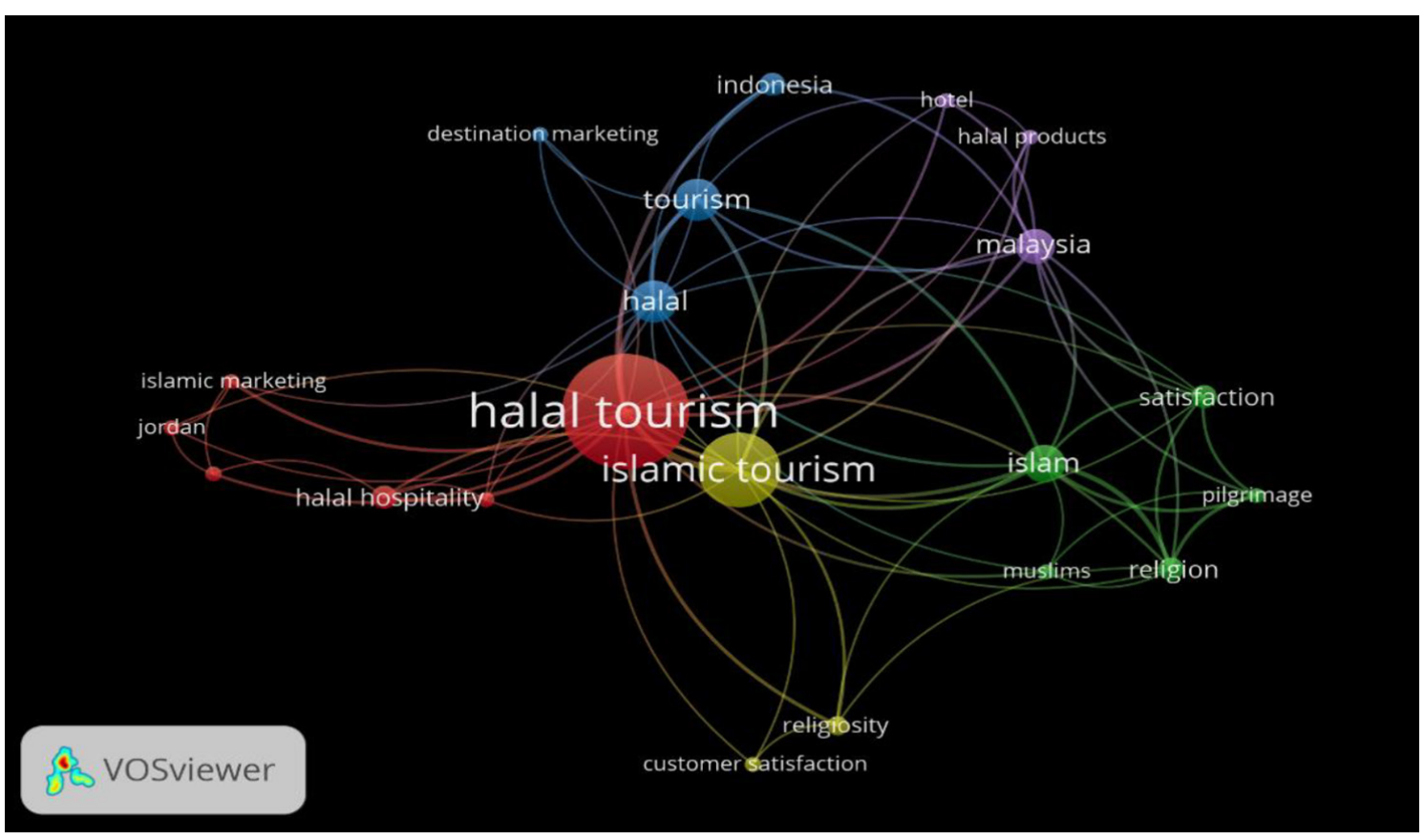

This paper is aimed to explore the subject of halal tourism by mapping out its development over 15 years with a thorough bibliometric analysis of 77 articles from the journals between 2004 and Sept 2020. The analyses in the previous section revealed the number of publications associated with halal tourism that has significantly increased over the years since its conceptualization. This trend in the publication is explained in two parts. The first part from 2004-2014 is the initial years of the halal tourism subject with a very minimal number of publications. Nevertheless, post-2015, in the second part, the literature on halal tourism initiates with a significant increase in publications every year. Out of the number of articles, the most cited article in the halal tourism subject is "Islamic tourism and managing tourism development in Islamic societies: The cases of Iran and Saudi Arabia” by Zamani-Farahani \& Henderson (2010) 159 citations.

Additionally, the most dominant authors are Henderson and Battour (total citations received); Al-Hamarneh and Steiner (in average citations per document). While for the highest number of publications associated with halal tourism is the Journal of Islamic Marketing in the highest rank with a total of 12 publications, and the International Journal of Tourism Research attests as the most dominant journal with 159 average citations per document; followed by Comparative Studies of South Asia, Africa, and the Middle East. Then, the University of Malaya and Nanyang Technological University are in the top list as the most dominant institutions on the total citations received and average citations per article. Finally, Malaysia attests as the most dominant country on the total citations received, while Singapore is the most dominant on the citations per article. The results give a picture of the most dominant contributors that significantly impact halal tourism and point out the increasing interest in halal tourism by prominent scholars and 
institutions globally. Moreover, based on the results of a co-citation analysis, it reveals that Henderson and Battour are the two most frequently cited authors in the subject of halal tourism. Further, there are five journals in the most frequently cited journals as the top contributors to halal tourism.

With regards to the co-occurrence of author keywords, nine keywords had been related to halal tourism. This result means the concept of halal tourism has broader aspects that researchers could explore. Meanwhile, six other encouraging keywords considerably could shape the future works of halal tourism.

\section{Conclusion}

This study attempt to complement the existing works on halal tourism by providing insightful content that adopts a systematic review. Each of the studies has limitations, including for this study despite the significant contribution of this study. One limitation is that this study adopted a single source or database for data collection and synthesis. Although other bibliometric researches were using a single database to avoid duplication, there are possibilities to include other methods in analyzing the literature on the halal tourism subject. Another limitation is the inability to capture a broader and deeper context of the citation structure of the articles. However, this study has sufficiently explained some other citation structures for the literature on halal tourism.

The study has some significant implications. Among others, it gives some important information on the dominant contributors to halal tourism, giving data on the most impactful studies, journals, and institutions that contribute to the halal tourism subject. The study also reveals the development and progression of the halal tourism subject over the years as well as disclosing the key research themes that emerge from the literature of halal tourism, and describes a comprehensive insight on the concept of halal tourism that can be used as a reference for any strategic initiatives.

Future research should focus on analyzing the concept from the lens of various other disciplines of study and expand to more dominant papers that are to be witnessed in this topic. Moreover, it is suggested to continue carrying out such bibliometric studies on halal tourism within intervals of every five years, thus contributing to the theoretical development. Finally, the literature review using bibliometric analysis can be carried out through a wide array of techniques, which are more than three techniques adopted by this study.

\section{References}

Abror, A., Wardi, Y., Trinanda, O., \& Patrisia, D. (2019). The Impact of Halal Tourism, Customer Engagement on Satisfaction: Moderating Effect of Religiosity. Asia Pacific Journal of Tourism Research, 24(7), 633-643.

AFP. (2015). Near Bali, Lombok Invests in Sharia Tourism. Japan Times. Retrieved from: http://www.japantimes.co.jp/news/2015/02/23/world/near-bali-lombok-invests-insharia-tourism/ 
Ala-Hamarneh, A. (2011). Islamic Tourism: a Long Term Strategy of Tourist Industries in the Arab World After 9/11. Centre for Research on the Arab World. Retrieved from: www.staff.unimainz.de/alhamarn/Islamic\%20Tourism\%20\%20paper\%20for\%20 BRISMES\%202004

Al-Hamarneh, A., \& Steiner, C. (2004). Islamic Tourism: Rethinking the Strategies of Tourism Development in the Arab World After September 11, 2001. Comparative Studies of South Asia, Africa and the Middle East, 24(1), 173-182.

Battour, M. M., Ismail, M. N., \& Battor, M. (2010). Toward a Halal Tourism Market. Tourism Analysis, 15(4), 461-470.

Battour, M., \& Ismail, M. N. (2016). Halal Tourism: Concepts, Practises, Challenges and Future. Tourism Management Perspectives, 19, 150-154.

Battour, M., Ismail, M. N., Battor, M., \& Awais, M. (2017). Islamic Tourism: An Empirical Examination of Travel Motivation and Satisfaction in Malaysia. Current Issues in Tourism, 20(1), 50-67.

Battour, M., Hakimian, F., Ismail, M., \& Boğan, E. (2018). The Perception of NonMuslim Tourists Towards Halal Tourism. Journal of Islamic Marketing, 9(4), 823-840. https://doi.org/10.1108/JIMA-07-2017-0072.

Bhuiyan, M. A. H., Siwar, C., Ismail, S. M., Islam, R., \& Ehsan, D. (2011). Potentials of Islamic Tourism: A Case Study of Malaysia on East Coast Economic Region. Australian Journal of Basic and Applied Sciences, 5(6), 1333-1340.

Boğan, E., \& Sarışık, M. (2019). Halal Tourism: Conceptual and Practical Challenges. Journal of Islamic Marketing, 10(1), 87-96. https://doi.org/10.1108/JIMA-06-2017-0066.

Calderwood, E. (2014). The Invention of Al-Andalus: Discovering the Past and Creating the Present in Granada's Islamic Tourism Sites. The Journal of North African Studies, 19(1), 27-55.

Carboni, M., \& Janati, M. H. I. (2016). Halal Tourism de Facto: A Case from Fez. Tourism Management Perspectives, 19, 155-159.

Carboni, M., Perelli, C., \& Sistu, G. (2014). Is Islamic Tourism a viable option for Tunisian tourism? Insights from Djerba. Tourism Management Perspectives, 11, 1-9.

Collins-Kreiner, N., \& Wall, G. (2015). Tourism and Religion: Spiritual Journeys and Their Consequences. In: Brunn S (Eds). The Changing World Religion Map, 689707. Netherlands: Springer.

Delaney, B. (2015). Lombok: Beyond the Islamic Tourism Drive, It Can be an Island for Everyone. The Guardian. Retrieved from: http://www.theguardian.com/travel/2015/ feb/26/lombok-beyond-the-islamic-tourism-drive-it-can-be-an-island-for-everyone

Duman, T. (2011). Value of Islamic Tourism Offering: Perspectives from the Turkish Experience. Proceeding World Islamic Tourism Forum (WITF), Kuala Lumpur, Malaysia.

El-Gohary, H. (2016). Halal Tourism, is it Really Halal?. Tourism Management Perspectives, 19(Part B), 124-130. https://doi.org/10.1016/j.tmp.2015.12.013. 
FICCI Religious Tourism Report. (2012). Diverse Beliefs: Tourism of Faith Religious Tourism Gains Ground. Retrieved from: http://www.ficci.com/spdocument/20207/DiverseBeliefs-Tourism-of-Faith.pdf

Henderson, J. C. (2009). Islamic Tourism Reviewed. Tourism Recreation Research, 34(2), 207-211.

Henderson, J.C. (2010). Sharia-Compliant Hotels. Tourism and Hospitality Research, 10 (3), 246-254.

Henderson, J. C. (2016). Halal Food, Certification and Halal Tourism: Insights from Malaysia and Singapore. Tourism Management Perspectives, 19, 160-164.

Isa, S. M., Chin, P. N., \& Mohammad, N. U. (2018). Muslim Tourist Perceived Value: a Study on Malaysia Halal Tourism. Journal of Islamic Marketing, 9(2), 402420. https://doi.org/10.1108/JIMA-11-2016-0083.

Ismail, M. N., Othman, R., \& Ismail, M. S. (2019). Halal Tourism Research Bibliometric Analysis in Scopus, ProQuest and Ebscohost. Proceeding in International Halal Conference, Univeriti Teknologi MARA, Kelantan.

Jafari, J., \& Scott, N. (2014). Muslim World and Its Tourisms. Annals of Tourism Research, 44, 1-19.

Kartal, B., Tepeci, M., \& Atl1, H. (2015). Examining the Religious Tourism Potential of Manisa, Turkey with a Marketing Perspective. Tourism Review, 70(3), 214-231. https://doi.org/10.1108/TR-09-2013-0048.

Khan, F., \& Callanan, M. (2017). The "Halalification" of Tourism. Journal of Islamic Marketing, 8(4), 558-577. https://doi.org/10.1108/JIMA-01-2016-0001.

Mohsin, A., Ramli, N., \& Alkhulayfi, B. A. (2016). Halal Tourism: Emerging Opportunities. Tourism Management Perspectives, 19, 137-143.

Neveu, N. (2010). Islamic Tourism as an Ideological Construction: A Jordan Study Case. Journal of Tourism and Cultural Change, 8(4), 327-337.

Osman, N. (2013). Sharia Tourism Initiated to Tap Growing Muslim Travel Market. The Jakarta Post. Retrieved from: http://www.thejakartapost.com/news/2013/01/07/ sharia-tourism-initiated-tap-growing-muslim-travel-market.html

Razzaq, S., Hall, C. M., \& Prayag, G. (2016). The Capacity of New Zealand to Accommodate the Halal Tourism Market -Or Not. Tourism Management Perspectives, 18, 92-97.

Ryan, C. (2016). Halal Tourism. Tourism Management Perspectives, 19, 121-123.

Samori, Z., Salleh, N. Z. M., \& Khalid, M. M. (2016). Current Trends on Halal Tourism: Cases on Selected Asian Countries. Tourism Management Perspectives, 19, 131-136.

Stephenson, M. L., Russell, K. A., \& Edgar, D. (2010). Islamic Hospitality in the UAE: Indigenisation of Products and Human Capital. Journal of Islamic Marketing, 1(1), 9-24.

Tajzadeh, N. A. A. (2013). Value Creation in Tourism: An Islamic Approach. International Research Journal of Applied and Basic Sciences, 4(5), 1252-1264. 
Vargas-Sánchez, A., \& Moral-Moral, M. (2019). Halal Tourism: State of The Art. Tourism Review, 74(3), 385-399. https://doi.org/10.1108/TR-01-2018-0015.

Wardi, Y., Abror, A., \& Trinanda, O. (2018). Halal Tourism: Antecedent of Tourist's Satisfaction and Word of Mouth (WOM). Asia Pacific Journal of Tourism Research, 23(5), 463-472.

Yagmur, Y., Ehtiyar, R., \& Aksu, A. (2019). Evaluation of Halal Tourism in Terms of Bibliometric Characteristics. Journal of Islamic Marketing, 11(6), 1601-1617. https:// dri.org/10.1108/JIMA-05-2019-0101.

Zamani Farahani, H., \& Henderson, J. C. (2010). Islamic Tourism and Managing Tourism Development in Islamic Societies: The Cases of Iran and Saudi Arabia. International Journal of Tourism Research, 12(1), 79-89.

Zhao, D., \& Strotmann, A. (2015). Analysis and Visualisation of Citation Networks. Synthesis Lectures on Information Concepts, Retrieval, and Services, 7(1), 1-207. 